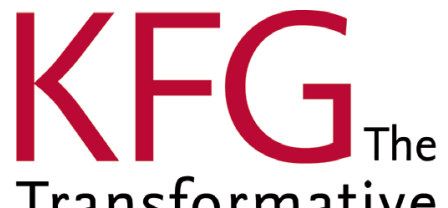

Transformative Power of Europe

\title{
The Transformative Power of Europe
}

The European Union and the Diffusion of Ideas

Tanja A. Börzel and Thomas Risse

NR. 1 | MAY 2009 


\section{KFG Working Paper Series}

\section{Edited by the Kolleg-Forschergruppe „The Transformative Power of Europe“}

The KFG Working Paper Series serves to disseminate the research results of the Kolleg-Forschergruppe by making them available to a broader public. It means to enhance academic exchange as well as to strenghen and broaden existing basic research on internal and external diffusion processes in Europe and the European Union.

All KFG Working Papers are available on the KFG website at www.transformeurope.eu or can be ordered in print via email to transform-europe@fu-berlin.de.

Copyright for this issue: Tanja A. Börzel/Thomas Risse

Editorial assistance and production: Farina Ahäuser/Mareike Bibow

Freie Universität Berlin

Kolleg-Forschergruppe

„The Transformative Power of Europe:

The European Union and the Diffusion of Ideas"

Ihnestr. 26

14195 Berlin

Germany

Phone: +49 (0)30- 83857033

Deutsche

Fax: +49(0)30- 83857096

transform-europe@fu-berlin.de 


\title{
The Transformative PoWer of EUROPe
}

\section{The EUROPEAN UnION AND THE DIfFUSION OF IDEAS}

\author{
Tanja A. Börzel and Thomas Risse \\ Freie Universität Berlin
}

\begin{abstract}
This paper sets out the research agenda of the Kolleg-Forschergruppe "The Transformative Power of Europe. The European Union and the Diffusion of Ideas". The diffusion of ideas has become a central research theme in political science, sociology, law, history, and economics. In this context, the KollegForschergruppe focuses on the theoretical and methodological challenges of identifying scope conditions for and interaction effects between the various causal mechanisms by which ideas are spread across time and space. We concentrate on the European Union (EU) as an almost ideal laboratory for investigating processes and outcomes of diffusion. First, European integration itself can be described as an effort to promote the diffusion of ideas across Europe and beyond. Second, European societies and polities emulate each other through mimetic processes. Third, Europe and the EU also serve as active promoters of diffusion processes toward the outside world. Last not least, European integration is embedded in and responds to larger global diffusion processes. The Kolleg-Forschergruppe will explore the diffusion of ideas in three thematic areas: "identity and the public sphere," "compliance, conditionality, and beyond," and "comparative regionalism and Europe's external relations".
\end{abstract}

\section{The Authors}

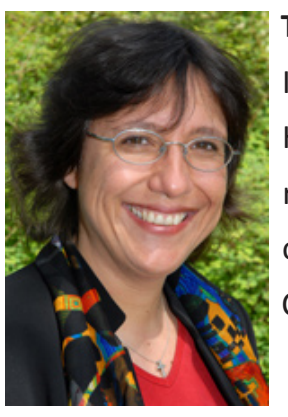

Tanja A. Börzel is professor of political science and holds the chair for European Integration at the Otto Suhr Institute of Political Science, Freie Universität Berlin. Her research concentrates on questions of Governance, institutional change as a result of Europeanization as well as on the diffusion of ideas and policies within and outside of the European Union. Since October 2008, she coordinates the Research College "The Transformative Power of Europe" together with Thomas Risse.

Thomas Risse is professor of international relations and director of the Center for Transnational Relations, Foreign and Security Policy at the Otto Suhr Institute of Political Science, Freie Universität Berlin. His major research interest lies in the field of Transatlantic Relations, Governance in Areas of Limited Statehood and European Public Sphere. Since October 2008, he coordinates the Research College "The Transformative Power of Europe" together with Tanja A. Börzel.

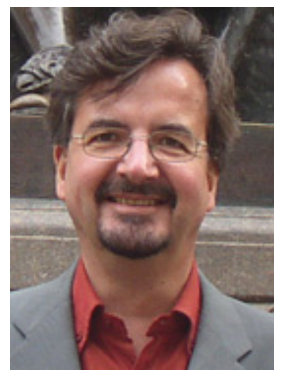




\section{Contents}

1. Introduction

2. The Diffusion of Ideas: Process and Outcomes 5

3. Zooming in: Mechanisms of Diffusion 9

4. The Road Ahead 14

Research Area 1: Identity and the Public Sphere 14

Research Area 2: Compliance, Conditionality and Beyond 15

Research Area 3: Comparative Regionalism and Europe's

$\begin{array}{ll}\text { Literature } & 19\end{array}$ 


\section{Introduction}

The diffusion of ideas has become a central research theme in political science, sociology, law, history, and economics. In studying how ideas are spread across time and space, scholars have focused on several questions: under which conditions does diffusion occur, what are the mechanisms of diffusion, which actors are involved in diffusion processes, which factors promote and retract diffusion, and how does diffusion affect political, social, cultural, legal, and economic conditions (for overviews see simmons et al. 2006; Holzinger et al. 2007a; Strang/Soule 1998)? Scholarly interest in the diffusion of ideas has grown irrespective of researchers' meta-theoretical orientations, such as rational choice or social constructivism (see e.g. Fehr/Gächter 2002; Fehr/Rockenbach 2003; Powell/DiMaggio 1991).

The European Union (EU) serves as an almost ideal laboratory for investigating processes and outcomes of diffusion. First, European integration itself can be described as an effort to promote the diffusion of ideas across Europe. Europeanization research has investigated the domestic effects of these diffusion processes in the current and future member states of the EU. Second, this vertical diffusion of ideas has to be contrasted with horizontal processes of diffusion. European societies and polities emulate each other through mimetic processes as well as learning. Third, Europe and the EU also serve as active promoters of diffusion processes toward the outside world. The EU has various policies in place to diffuse its ideas - both in its immediate neighbourhood and worldwide. At the same time, European ideas are being emulated across the globe - from Mercosur in Latin America to the African Union and the newest attempts at regional integration in Asia. Finally, European integration is itself embedded in and responds to larger global diffusion processes - economically, politically, and culturally.

The diffusion of ideas is not a process free of conflict, resistance, and politics. European efforts to diffuse values, norms, and rules - both internally as well as externally - have to cope with heterogeneity and diversity. Since they often do not resonate with the domestic structures of their recipients, European ideas often face political contestation and social mobilization. Citizens - the ultimate recipients of attempts at diffusion - may not like what they see - as experienced in 2005 when French and Dutch citizens rejected the Constitutional Treaty. As a result, diffusion processes inside and outside Europe have not produced homogeneity and convergence. Europeanization has not led to the disappearance of national institutional and cultural differences. Nor has the emulation of European ways of doing things resulted in similar models of regional integration across the globe. Historical, social and cultural factors may significantly mitigate and refract the diffusion of ideas, inside and outside the EU. European ideas are particularly influential if they resonate with the social, political, economic, cultural and historical conditions of the receiving countries.

\section{The Diffusion of Ideas: Process and Outcomes}

The Kolleg-Forschergruppe focuses on the EU as both subject and object of the diffusion of ideas. We understand diffusion as a process through which ideas are spread across time and space (cf. Strang/Meyer 1993). We concentrate in particular on two dimensions of ideas that can be diffused (see e.g. Goldstein/ Keohane 1993; Rein/Schön 1991; Lepsius 1990): 
- Cognitive dimension of ideas, such as causal beliefs or knowledge, that is collectively shared validity claims with regard to cause- and effect-relationships and states of the world;

- Normative dimension of ideas, for example principled beliefs or norms as collectively shared expectations about appropriate behaviour on the basis of a given identity (see Jepperson et al. 1996).

Ideas are embedded in and influence social processes and structures on various levels (see Jachtenfuchs 1995). We will focus on ideas in their relationship with policies, interests, identities, and institutions. Policies on various levels encapsulate and promote both causal and normative ideas. Ideas also affect how actors perceive and articulate their interests and preferences. ${ }^{1}$ Moreover, ideas are part and parcel of how actors think of themselves and others - that is how they form their collective identities. And they form an intrinsic part of social structures insofar as social institutions can be regarded as cognitive and normative ideas "frozen in time" (see Sikkink 1991: 26).

The Kolleg-Forschergruppe investigates the diffusion of ideas in and through Europe and the EU by asking three sets of interrelated questions:

1. How and under what conditions do Europe and the EU function as promoter of ideas, both internally and externally? What diffusion mechanisms does it employ in which contexts?

2. What about Europe and the EU as recipients of diffusion processes at the global level? Which diffusion mechanisms are particularly conducive to transformational changes inside the EU and its member states?

3. What are the institutional effects of these diffusion processes on political, economic, social, and cultural structures and processes inside the EU and its member states, which factors promote and constrain the diffusion of ideas, and how are these differential effects to be explained?

To study the diffusion of ideas, both as process and outcome, we can draw on a vast literature. Large-n macro-quantitative studies have demonstrated, among others, the diffusion of state sovereignty (Strang 1990), of liberal economic policies (Simmons et al. 2006), of democracy and human rights (Huntington 1991; Starr 1991; Gleditsch/ Ward 2006), of technology and management practices (Mansfield/Milner 1999; Rogers 2003; Keller 2002), of mass schooling (Meyer et al. 1992), or of new environmental policy instruments (Tews et al. 2003; Holzinger et al. 2003). ${ }^{2}$ In the international relations literature, the socalled "second image reversed" approach (Gourevitch 1978) has analyzed how international institutions impact upon the domestic structures of states (Milner 1988; Keohane/Milner 1996). A similar perspective has been adopted by students of European integration who seek to identify conditions under which European institutions, policies and processes affect member states (Cowles et al. 2001; Graziano/Vink 2006; Bach 2000; overview in Börzel/Risse 2007). In both literatures, compliance with international and

1 We do not subscribe to a simplistic "ideas versus interests" account. Irrespective of how one conceptualizes the relationship between material factors and ideas, suffice it to say at this point that a conceptualization of interests without taking ideational factors into account is highly questionable.

2 Pioneering research has been done by the "Stanford School" which has been tracing the global diffusion of norms and values as part of an emerging world culture and world society (Boli/Thomas 1999; Meyer et al. 1997). 
European policies, respectively, has been identified as a major route through which ideas may transform the behaviour, structures and identities of states (for an overview of the vast literature on compliance see Raustiala/ Slaughter 2002).

The literatures on policy diffusion, policy transfer and institutional isomorphism, ${ }^{3}$ both at the global and the national level, complement the research on internationalization and Europeanization. First, they systematically consider the generation and diffusion of ideas by norm- or policy-entrepreneurs, for example through the building or shaping of institutions (Finnemore/Sikkink 1998; Payne 2001). Second, these literatures also specify more indirect mechanisms through which ideas can spread. They do not necessarily require the intentional action of a norm- or policy-entrepreneur. Actors may decide to emulate others by adopting certain ideas to improve their performance or obtain greater legitimacy (DiMaggio/ Powell 1983; Meyer/Rowan 1977). This is particularly likely if institutions frequently interact and are exposed to each other or are located in a similar environment with stable, formalized and clear-cut organizational structures (Meyer/Rowan 1991; DiMaggio 1991; Strang/Meyer 1993; Scott/Meyer 1994).

The social science research on policy diffusion, policy transfer and isomorphism resonates well with the debates in economics on the diffusion of ideas at the international level and within federations through learning, information spill-overs, and factor mobility. Under the headline of "yardstick competition," economists discuss the impact of comparative performance evaluation between different governments by voters, arguing that this will allow identification of good and bad policies and, ultimately, lead to the spread of policy ideas across borders and regions (Salmon 1987; Besley/Case 1995; Bordignon et al. 2004; Brueckner 2003 for a survey). A related mechanism, system competition, is based on the notion that increasing cross-border mobility of capital will lead, among other things, to a harmonization of national and regional regulatory and tax systems (Tiebout 1956; Sinn 2003; Wilson 1999 for an overview). Finally, economists have taken a keen interest in the determinants of the diffusion of "best practices" in the design of important policy institutions such as central banks (Berger et al. 2001) and fiscal policy (Hallerberg et al. 2004). Often these institutional changes combine elements of coercion and emulation. A case in point is the harmonization of central bank independence within the EU both prior and after the decision to introduce the Euro and the evolution of the Euro zone's fiscal institutions since the late 1990s. Finally, economists have started to debate whether diffusion is always based on strategic choices or may also result from "contagious" herd behaviour triggered by sequential learning (Banerjee 1992; Kaminisky/ Reinhart 2000; on diffusion as contagion see also Levi-Faur 2002 and Myers 2000).

In addition, legal scholars have long studied the diffusion of legal ideas from a historical perspective. The influence of Roman law on the development of the continental or civil law systems (Wieacker 1967; Zimmermann 1996) or the global rise of the protection of fundamental rights after the Second World War are striking examples (Stern 2003). The Council of Europe and, in particular, the European Convention of

3 While representing different literatures and disciplines of social sciences, theoretical arguments on policy diffusion, policy transfer and institutional isomorphism focus on similar causal mechanisms. While organizational theory refers to "coercive, normative and mimetic isomorphism" (DiMaggio/Powell 1983), research on policy transfer speaks of "direct coercive, indirect coercive, and voluntary transfer" (Dolowitz/Marsh 1996; Evans/ Davies 1999). Institutional isomorphism is rather structure-oriented while policy transfer and policy diffusion focus more on the role of agency. Policy diffusion, in turn, is mostly concerned with process. Policy transfer is more interested in policy goals, content and instruments (Cf. Dolowitz/Marsh 2000; Holzinger et al. 2007b). The Europeanization literature has sought to integrate the various concepts (Cf. Radaelli 2000a, Radaelli 2000b). 
Human Rights was - and continues to be - a major factor in the promotion of democracy, the rule of law and human rights throughout Europe (ECHR 1950). The transfer of ideas from one country to the other and reciprocal learning processes regarding constitutional concepts and principles in Europe have not only supported the democratization processes in Greece, Spain and Portugal, and more recently, in Central and Eastern Europe, but even form a basis for a specific analytical approach in constitutional theory (Häberle 1992, 2006; Bogdandy et al. 2007). The transfer and adaptation of constitutional principles as well as legislation in areas such as corporate law, environment, and working conditions are also a condition for the accession of new members to the EU. But legal harmonization is not a one-way street. The EU constitutional law as well as its secondary legislation reflect the general principles and traditions of the member states' constitutional law or are inspired by specific solutions found at the national level (Pernice 2001). Important recipients of European ideas are Japan, Korea, China or Latin America in areas, such as private law, criminal and administrative law. Such forms of "legal transplants" (Watson 1974) and transfer processes are increasingly acknowledged as global practice, but there is little systematic analysis on their conditions, structures and effects (Jackson/Tushnet 1999; Rosenfeld et al. 2003).

Last not least, the study of diffusion requires an encounter with history, since ideas not only spread across space, but also across time (overview in Djelic 2007). Historians point to three concepts that help to historicize diffusion processes at the intersection of social science and historical analysis. First, historians emphasize contextualization. Ideas do not just spread across time, but meet specific historical and social contexts in which they are adapted and transformed (see e.g. Westney 1987; Djelic 2007; Paulmann 2004; Grazia 2005). Second, contextualization of ideas requires "translation," from one historical time and cultural setting to another. Such translation processes may involve appropriation, resistance, and reinterpretation. They encompass generational leaps (time) but also cultural differences (space) (cf. Randeria 1999; Randeria/Conrad 2002; Werner/Zimmermann 2002). Third, the concept of path dependence which historical institutionalists also emphasize (see e.g. Steinmo et al. 1992) needs to be considered. It "characterizes specifically those historical sequences in which contingent events set into motion institutional patterns of event chains that have deterministic properties" (Mahoney 2000: 507). In sum, the historicization of diffusion processes makes us aware of the fact that active construction and reconstruction plays a significant role in the spread of ideas over time and space.

Bringing these various literatures and experiences together, we can identify different mechanisms for the diffusion of ideas resulting in various degrees of social change and transformation (see figure 1). ${ }^{4}$ While these mechanisms themselves are widely quoted in the literature, the theoretical and methodological challenge of our Kolleg-Forschergruppe will be to identify the scope conditions of and the interaction effects between the various diffusion mechanisms.

4 For similar approaches see Diez et al. (2006); Holzinger et al. (2007b); Schimmelfennig/Sedelmeier (2004); Simmons et al. (2006); Johnston (2007). 


\section{Zooming in: Mechanisms of Diffusion}

The diffusion mechanisms identified in the literature can be subsumed under three major logics of social action that rest on distinct assumptions about actors and their relations with social structures and institutions (cf. March/Olsen 1998; Habermas 1981; Risse 2000: 1) instrumental rationality or rational choice; 2) normative rationality or logic of appropriateness; 3) communicative rationality or logic of arguing. The three lines of theorizing give rise to different expectations when and how actors seek to promote ideas and decide to adopt them, respectively. ${ }^{5}$ Based upon the three logics of social action, we identify five different mechanisms (summarized in figure 1).

Figure 1: Mechanisms of Diffusion

\begin{tabular}{|c|c|c|}
\hline $\begin{array}{l}\text { Social mechanism and } \\
\text { underlying theory of social } \\
\text { action }\end{array}$ & Promoter of Ideas (Sender) & Recipient of Ideas \\
\hline $\begin{array}{l}\text { Coercion } \\
\text { (legal and physical imposition) }\end{array}$ & $\begin{array}{l}\text { coercive authority (Herrschaft), } \\
\text { legal or physical force }\end{array}$ & obedience, submission \\
\hline $\begin{array}{l}\text { Manipulation of } \\
\text { Utility Calculations } \\
\text { (instrumental rationality) }\end{array}$ & $\begin{array}{l}\text { (positive) and (negative) } \\
\text { incentives }\end{array}$ & $\begin{array}{l}\text { reward (reap benefits) } \\
\text { punishment (avoid costs); } \\
\text { adaptive learning }\end{array}$ \\
\hline $\begin{array}{l}\text { Socialization } \\
\text { (normative rationality) }\end{array}$ & $\begin{array}{l}\text { promote ideas through } \\
\text { providing an authoritative } \\
\text { model (normative pressure) }\end{array}$ & $\begin{array}{l}\text { internalization of ideas; } \\
\text { identity change to gain social } \\
\text { acceptance }\end{array}$ \\
\hline $\begin{array}{l}\text { Persuasion } \\
\text { (communicative rationality) }\end{array}$ & $\begin{array}{l}\text { promote ideas as legitimate or } \\
\text { true through reason-giving }\end{array}$ & $\begin{array}{l}\text { reasoned consensus } \\
\text { (acceptance of idea as } \\
\text { legitimate or true); complex } \\
\text { learning; identity change }\end{array}$ \\
\hline $\begin{array}{l}\text { Emulation (indirect influence) } \\
\text { a) lesson - drawing } \\
\text { (instrumental rationality) } \\
\text { b) mimicry } \\
\text { (normative rationality) }\end{array}$ & $\begin{array}{l}\text { (Promote comparison and } \\
\text { competition - strictly speaking } \\
\text { this mechanism does not } \\
\text { require the active promotion of } \\
\text { ideas) }\end{array}$ & $\begin{array}{l}\text { a) performance (adopt } \\
\text { effective and efficient policy } \\
\text { solution) } \\
\text { b) imitation (become more } \\
\text { like the relevant peers) }\end{array}$ \\
\hline
\end{tabular}

The first mechanism, which is often overlooked in the literature assuming voluntary diffusion of ideas, concerns coercion. Actors may simply have no choice but to accept an idea because they are forced by the threat or the actual use of physical violence (Hurd 1999). Strictly speaking, coercion is only relevant with regard to the internal diffusion of ideas (Europeanization) as part of the member states' obligation to comply with EU law. Member states of the European Union are subject to ideas diffused by the case law of the European Court of Justice (Shapiro 1992) or European directives harmonizing national legislations

$5 \quad$ Note that the following mechanisms represent ideal types. Ideas diffuse in such a complex process that several mechanisms should be assumed at work simultaneously in a given empirical situation. 
(Scharpf 2003; Börzel 2007). In a historical perspective, however, coercion plays a more prominent role (cf. Owen 2002). Not only did European powers impose ideas on their colonies, often justified along a mission to civilize (see the French “mission civilisatrice” or the British “White Man's Burden"). Europe itself has been subject to attempts at coercive diffusion at various times in its history.

The second mechanism concerns diffusion of ideas through the manipulation of utility calculations by providing negative and positive incentives. Actors seek to promote certain ideas to realize individual gains, such as getting access to new markets, or to avoid costs, for example by stabilizing a political situation in neighbouring countries that creates negative externalities, such as civil wars. In a similar vein, the promoters of ideas can induce other actors into adopting their ideas by manipulating their utility functions. They provide rewards, for example in form of financial and technical assistance, or incur costs through sanctions or empowering domestic actors who push for the adoption of the idea (Keohane 1984; Legro 1997; Weitsmann/Schneider 1997). The supply of causal ideas can also result in adaptive or "Baysian" learning (Simmons et al. 2006: 796) if actors receive new information that permits updating their beliefs for example about how to best reach a certain policy goal (Meseguer 2006).

Concerning internal diffusion, the EU has quite a few instruments at its disposal to induce member states to adopt certain policies through rewards and sanctions (cf. Börzel 2003b; Tallberg 2003). While internal diffusion processes are well researched, this is less the case with regard to the EU efforts to export certain ideas to the global level and their projection into third countries, respectively (external diffusion). To a certain degree, the EU has used the externalization of European ideas to pursue its own instrumental interests, such as security, stability, prosperity and environmental protection. In the accession process of the Central, Eastern, and South Eastern European countries, the EU and the member states have mostly relied on external incentives or reinforcement through rewards, on the one hand, and capacitybuilding, on the other (Schimmelfennig/Sedelmeier 2005; Kelley 2004; Vachudova 2005; Dimitrov et al. 2006). But while the effects of European ideas on the candidate countries have been immediate and fast, conditionality appears to be far less effective with countries that are either not willing or not capable of adopting European ideas because they do not resonate with domestic structures and identities or they lack the necessary capacities to introduce required changes (Youngs 2001; Holland 2003; Magen/Morlino 2008). Yet, alternative mechanisms, such as socialization, persuasion and emulation, have received little attention in the literature so far.

The third and the fourth mechanisms draw on logics of social action theorized by social constructivism that also resonates with historical work on diffusion. Socialization works through normative rationality or the logic of appropriateness (March/Olsen 1989, 1998) which differ from strategic and instrumental behaviour in that actors seek to do "the right thing" rather than maximizing or optimizing their given utilities. Actors learn to internalize new norms and rules in order to become members of (international) society "in good standing" (Finnemore/Sikkink 1998). Such processes of socialization often result in complex learning by which actors redefine their interests and identities (Checkel 2005; Johnston 2007). They can also work through habitualization. By talking the talk, actors may change their social practices and dispositions, finally ending up walking the walk.

Persuasion is based on communicative rationality or the logic of arguing. It refers to situations in which actors try to persuade each other about the validity claims inherent in any causal or normative statement. 
Arguing involves reason-giving and challenging these claims as well as the legitimacy of norms. While some authors emphasize the role of international organizations, which "teach" state actors international ideas (Finnemore 1996; Checkel 2001), others focus on the role of (trans)national non-governmental organizations as promoters of ideas (Keck/Sikkink 1998; Haas 1992).

Once again, socialization and persuasion processes contain an internal and an external dimension with regard to the EU. The emerging literatures on the Europeanization of national identities, values, as well as of public spheres provide a good example for internal diffusion processes of ideas about who "we" are and how we engage each other in the public sphere (see e.g. Gerhards/unter Mitarbeit von Michael Hölscher 2005; Herrmann et al. 2004; Kantner 2004; Trenz 2006b; Koopmans 2004; Jachtenfuchs et al. 1998). While these literatures are increasingly well developed with regard to descriptive inferences about the evolution and diffusion of identities and values, we have very little systematic knowledge about its causes and its effects on European policies and politics, particularly when European ideas are contested and meet with resistance.

With regard to the external diffusion of ideas via socialization and persuasion, the EU also provides a rich laboratory. The EU and its member states do not merely promote democracy and human rights as normative standards in their external relations with third countries. These ideas also constitute causal beliefs since they are considered as the best way to ensure (regional) security, stability and prosperity at the EU's borders and beyond (see Magen 2006). The same is true for specific policy areas, such the environment. The Kyoto Protocol is a telling example of how the EU sought to persuade other states that legally binding emission standards are a more effective instrument to reduce greenhouse gas emissions than economic and voluntary measures (Jachtenfuchs 1996; Scheipers/Sicurelli 2007; Schreurs 2004a). Finally, the export of ideas which build upon the very foundations of the European Union, has served to construct a distinct foreign policy identity (Manners 2002; Diez 2005; Manners/Whitman 2003). In its external relations, the EU and the member states seek to persuade state actors to adopt this model through processes of arguing and persuasion in institutionalized patterns of political dialogue and cooperation (cf. Youngs 2001). In this context, the question has to be asked to what extent the EU diffuses distinctively European ideas. Human rights, democracy, open market or multilateralism can be seen as part of the global diffusion of a wider international order promoted by "Western" countries and international organizations (Gleditsch/Ward 2006; Epstein 2008).

While the EU and its member states as promoters of normative and causal ideas are pretty well researched, we know very little as to the effects of these attempts at diffusion which often meet with resistance and contestation on the ground. The diffusion literature tends to turn a blind eye to issues of (conflicting) interests and power and has paid little attention to unintended or "nasty" (Schimmelfennig 2007: 14) consequences. Thus, the EU's effort to export regionalism has crowded out and undermined endogenous region-building developments in the Baltic (Christiansen et al. 2000) and, arguably, also in Sub-Saharan Africa (Hurt 2003). The conditions under which efforts at socialization and persuasion work and to whose advantage are still under-researched. This is also the case for the EU as a target of socialization and persuasion where the EU becomes a taker of ideas promoted by international organizations and third countries. The EU has Europeanized ideas it received from the outside world, for example with regard to the liberalization of capital markets and telecommunications, but also concerning the re-regulation of firms and financial markets (Schneider 2001; Levi-Faur 2004; Lütz 2002; Lütz/Eberle 2007). To a certain 
extent, even European integration itself can be regarded as the diffusion of (American) ideas about the post-World War II European order (Gillingham 2003; Lundestad 1986; Majone 1991; Neuss 2000).

Equally neglected has been the fifth mechanism of emulation which does not require an active promoter of ideas, but relies on indirect influence. While there is a rich sociological literature on institutional isomorphism, emulation and mimicry (DiMaggio/Powell 1991; Powell/DiMaggio 1991), political science, economics, or history which are usually rather agency-centred, have yet to catch up with these studies. Indirect mechanisms of diffusion are largely based on the principle of competition (competitive isomorphism, cf. Hannan/Freeman 1977). Actors compete with each other over meeting certain performance criteria, for example creating employment or fostering economic growth, to which they unilaterally adjust their behaviour accordingly (Elkins et al. 2006; Vogel 1995; Busch et al. 2005). External actors may foster processes of emulation by promoting comparison and competition as the OECD or the European Union do among its members by setting bench-marks and organizing regular peer reviews (Rose 1991; Tews 2002; Jakobi/Martens 2007). Competition does not only entail the diffusion of ideas as normative standards for political or economic behaviour but also seeks to spread causal beliefs, for example by learning from best practice, on how to best reach these standards (Börzel 2007, Börzel/Risse forthcoming-b). Actors, in turn, borrow ideas in order to improve their performance (emulation) in comparison to others. Ideas may become "contagious" (Myers 2000: 175) under conditions of uncertainty, policy failure and dissatisfaction with the status quo, rather than external pressure. Actors look to others for policies and rules that effectively solved similar problems elsewhere and are transferable into the domestic context (Meyer/ Rowan 1977; Dolowitz/Marsh 2000; Goetz 2001). Next to lesson-drawing, which is based on instrumental rationality (cf. Rose 1993), actors may also emulate others for normative reasons, to increase their legitimization (symbolic imitation; cf. Polillo/Guillén 2005) or to simply imitate their behaviour because its appropriateness is taken for granted (mimicry; cf. Meyer/Rowan 1977; Haveman 1993).

Emulation processes are the least understood with regard to the EU. The Open Method of Coordination (OMC) is probably the most prominent example of internal diffusion through emulation (Hodson/Maher 2001). It comes closest to (managed) policy emulation, which is also enshrined in the principle of mutual recognition. The latter constitutes the framework for a moderate regulatory competition between the member states that helps to diffuse ideas, not only with regard to economic activities (Sun/Pelkmans 1995: 68f) but also in the area of asylum and immigration policy (Schmidt 2007). In its external relations, the EU and the member states have sought to encourage competition among countries seeking closer relations with the EU. While the EU's external relations have been largely structured around regional dimensions, countries negotiate bilateral agreements based on their performance with regard to adopting European ideas (Bauer et al. 2007).

Even less understood is the receiving end of emulation. We know very little about efforts by member states and non-member states to emulate EU practices through either lesson-drawing or simple mimicry. The accession countries, for example, emulated European ideas in policy areas in which the EU did not demand adjustment. They chose EU ideas rather than ideas from elsewhere in anticipation of having to adopt these ideas sooner or later anyway as part of their objective to achieve membership. With regard to the EU as a model of regional integration, the African Union serves as an example of emulating particular institutional arrangements without much EU interference (Farrell 2007). 
In sum, there is a rich theoretical literature on diffusion which we subsumed under different causal mechanisms. We also need to distinguish between various effects of diffusion processes on policies, interests, identities, and institutions (see above). On each of these levels, the effects of diffusion processes can range from more or less cosmetic change to large-scale transformation.

The literatures on diffusion processes and on Europeanization point to the following desiderata which the Kolleg-Forschergruppe will address:

- With regard to the internal diffusion of ideas in Europe (Europeanization), the spread of policies and regulatory practices including institutional designs is well researched. We know far less about the conditions under which identities Europeanize or variations in European identities and values arise, for example through processes of contestation. We also know little about diffusion processes and mechanisms in Europeanized public spheres and their effects on the construction of European identities among Europeans.

- The EU as an active promoter of causal and principled ideas in its external relations has given rise to a growing literature. But we know little about the long-term effects of these conscious efforts at diffusion and the conditions under which they yield what kind of results in terms of interest and identity changes. How does the EU respond to resistance and contestation to its attempts at diffusing ideas? To what extent are these ideas truly European and not general "Western" principles that are also promoted by non-European countries? Finally, how do the attempts at exporting European ideas compare to historical forms of external diffusion, such as colonialism?

- The recent literature has also neglected the role of EU as a taker of ideas, that is as subject of diffusion processes, be it through the conscious promotion of ideas by others (for example the U.S.), be it through indirect emulation or mimicry. This question is particularly interesting from a historical perspective since European integration has not only become a model to be emulated by other regions around the globe but has been shaped by external ideas.

- With regard to the mechanisms specified, the use and the effects of positive and negative incentives are well researched given the predominance of rational choice in EU studies. In contrast, we know rather little about the conditions under which efforts at socialization and persuasion yield which results (see, however, Checkel 2005). Moreover, the literature tends to treat the different mechanisms as alternative or even competing explanations. Potential interaction and feedback effects are hardly explored (cf. Braun/Gilardi 2006).

- This is even more the case for emulation processes that are based on indirect social influences without the active engagement of idea promoters. Lesson-drawing and/or mimicry is probably the least researched area both with regard to Europeanization as an internal process and with regard to the external diffusion of European ideas.

- Finally, the politics of diffusion, that is the role of power and interest, is often neglected. Moreover, the diffusion of ideas is often considered solely at the level of elites, while citizens' reactions and protests are not taken into consideration. Despite the image as a civilian power the EU seeks to promote, its attempts at diffusing ideas have often met with contestation, conflict and resistance, both within and outside the EU. Cases of failed diffusion have hardly been studied so far (for an exception see Eimer 2008). 
Concentrating on these neglected research fields will help us to tackle the major theoretical and methodology challenge of the Kolleg-Forschergruppe identified above, namely to specify the scope conditions of and interaction effects between the various causal mechanisms. This will be our main contribution to the larger literature on the diffusion of ideas.

\section{The Road Ahead}

The Kolleg-Forschergruppe "The Transformative Power of Europe" seeks to investigate Europe and the EU as agents of political, social, economic, legal, and cultural change inside and outside of Europe. And we examine Europe and the EU at the receiving end of global diffusion processes. The Kolleg-Forschergruppe will study the interaction between the generation of ideas, on the one hand, and the social, political, economical, cultural and historical conditions that facilitate and mitigate their diffusion, on the other. Seeking to tackle the three sets of research questions and the desiderata in the literature identified above, our common endeavour focuses on the following three research areas that have been at the core of our work:

\section{Research Area 1: Identity and the Public Sphere}

Political entities depend on bonds rooted in a feeling of belonging or identity. Without social ligatures, citizens are unlikely to accept majority decisions on highly controversial issues, nor are they willing to transfer parts of their own wealth to needy members of society. This research area will explore how the diffusion of ideas through and by the European Union affects collective identities and their Europeanization. To what extent has the internal diffusion of European ideas affected the emergence of common values and identities leading to an "imagined European community" among the citizens (Anderson 1991)? Can we observe a socialization process by which the new member states in Central Eastern Europe incorporate Europe and the EU into their collective identity narratives? And how can we explain these diffusion processes and their differential effects on the Europeanization of collective identities? How does the "politics of identity" affect these diffusion processes? What are the scope conditions of identity transformation in the European Union?

At the same time, the EU actively promotes a particular identity through its internal and external policies, but also through its accession criteria. In this context, the discursive constructions of European borders and the controversies about these borders (Does Turkey belong to "Europe"?) tell us a lot about the mechanisms through which European identities diffuse and to what extent they are contested. What are the cultural "borders" of Europe in these constructions? How do processes of "Othering", for example with respect to religious or gender identities, contribute to constitute these borders and how are they transgressed by constructions of hybrid identities and transnational communities (Harders 2004)?

A particular arena in which ideas are diffused and identities are constructed is the public sphere. More than ten years of empirical research on public spheres in Europe has shown the gradual Europeanization of public spheres as a result of which Europeans are increasingly enabled to meaningfully communicate across borders (see e.g. Kantner 2004; Trenz 2006a). The Kolleg-Forschergruppe will explore the consequences of 
Europeanized public spheres for the diffusion of ideas in Europe and beyond. In particular, it will examine European-wide transnational discourses and controversies as sites in which European identities are constructed as well as contested. How will the increasing politicization and contestation of EU economic and social policies in transnationalized and Europeanized public spheres impact upon the legitimization of EU policies?

With regard to collective identities and the public sphere, Thomas Risse has pursued an active research programme over the past ten years (Risse 1997, 2001, 2002, 2003, 2004a, 2004b, forthcoming; Risse et al. 1999; Risse/van de Steeg 2007). This research has demonstrated the Europeanization of national identities in the sense that "Europe" has been integrated in various national identity constructions. Yet, two competing visions of Europe appear to clash in these collective identity constructions, namely a modern political Europe based on the values of secularism and enlightenment, on the one hand, and a more traditional and culturally bound Europe with religious (Christian) undertones, on the other hand.

Risse's work is complemented by Jürgen Gerhards' sociological research on the European public sphere as well as on the cultural and value differences between old and new EU member states (e.g. Gerhards 2007; Gerhards/unter Mitarbeit von Michael Hölscher 2005). Markus Jachtenfuchs (political science) and Ingolf Pernice (law) contribute to the research area their expertise on the diffusion of constitutional ideas in the European Union (Jachtenfuchs 1995, 2002; Jachtenfuchs et al. 1998; Pernice 2004, 2005), while Cilja Harders (political science) brings to it her scholarship on the construction of religious and gender identities, particularly in the processes of boundary construction between Europe and the Arab world (Harders 2002, 2004). Last not least, Ursula Lehmkuhl (history) will help us to put our findings in a historical perspective and to explore the degree to which contemporary narratives about European identity and the public sphere reflect and are embedded in the construction of historical memories (see e.g. Lehmkuhl 2000, 2001). Our research group will greatly benefit from guest scholars from the Fellow Program. In particular, we plan to expand our expertise in the fields of law, sociology, and history through inviting external senior and junior fellows to contribute to our work.

Thus, the Kolleg-Forschergruppe will enable us to synthesize our work on the mechanisms by which normative and causal ideas spread in transnationalized public spheres and affect collective identities. While we concentrate on Europe and the EU as our empirical domain, we aim at generalizable knowledge on the diffusion of collective identities and the emergence of public spheres beyond the nation-state.

\section{Research Area 2: Compliance, Conditionality, and Beyond}

The EU as a "normative power" promotes ideas that often create serious adaptation problems both for its member states and third countries. How and to what extent have European ideas transformed the politicaladministrative, economic, social, and cultural institutions of nation-states within and outside the EU? To what degree does the diffusion of European ideas result in institutional convergence, and what explains the persisting differences? Which conditions foster and retract the diffusion of European ideas? Who are the agents of change? Most importantly, how do the different diffusion mechanisms interact? How do "soft" and more indirect diffusion mechanisms, such as socialization, persuasion, emulation and mimicry, compare to conditionality and coercion in terms of effectiveness, particularly if European ideas meet with 
contestation and resistance? Are socialization and persuasion functional equivalents to the provision of incentives or do they reinforce each other? They could also be linked sequentially with socialization and persuasion locking-in the more immediate effects of incentives. Finally, the different mechanisms could undermine each other resulting in unintended or even "nasty" consequences.

Tanja Börzel has conducted several research projects on compliance with EU policies in member states, accession countries and neighbourhood states (Börzel 2001, 2003a, 2006, Börzel forthcoming-a, Börzel et al. 2003, 2007a, 2007b, forthcoming; Börzel/Risse 2002). Her research shows that the effectiveness of legal coercion and the manipulation of utility calculations are seriously mitigated by the power and capacities of the recipient countries.

The country and policy expertise of Klaus Goetz (Goetz 2001, 2005, 2006), Cilja Harders (Harders 2002, 2004), Markus Jachtenfuchs (Jachtenfuchs 2001, 2005), Susanne Lütz (Lütz 2004; Lütz/Eberle 2007) and Miranda Schreurs (Schreurs 2004a, 2004b) will help to explore the question to what extent experiences from member states and candidate countries can be extended beyond Europe, that is to countries that are not eligible for membership (particularly the Mediterranean and post-Soviet countries in the EU's neighbourhood). Together with guest scholars, the members of the Kolleg-Forschergruppe will investigate which ideas are diffused, intentionally and unintentionally, beyond the integrated Europe and whether these ideas are distinctively European and differ from the values and norms promoted by other actors, such as the U.S., NATO, the OECD, the U.N., the OSCE or the Council of Europe. Moreover, the theoretical works of Helge Berger (Berger et al. 2001, 2007), Jürgen Gerhards (Gerhards 2000, 2007), Ingolf Pernice (Pernice 2001), and Ursula Lehmkuhl (Lehmkuhl 2001) will broaden the political science perspective in studying the mechanisms of diffusion beyond the current and would-be members of the EU. Adopting a multidisciplinary approach, the group will explore how important learning and competition, in the political (yardstick) and economic (taxation and regulation) sphere, are compared to more coercive forces such as the centralized harmonization of laws within the EU or the standardized accession process for potential members. Special focus will be placed on the extent to which socialization and emulation are more effective in ensuring sustainable compliance with and internalization of European ideas resulting in transformation rather than what Goetz has called "shallow Europeanization" (Goetz 2005: 262). The Fellow Programme will allow gaining additional expertise, particularly with regard to ideas' promoters other than the EU and the historical dimension of the diffusion of ideas within and into Europe and the EU.

Thus, the Kolleg-Forschergruppe will provide the opportunity to bring together the empirical and theoretical findings from various projects. It will enable us to systematically theorize the conditions for the effective diffusion of European ideas in different contexts that vary with regard to the type of countries targeted by the $\mathrm{EU}$ and the prominence of the mechanisms the EU draws on to induce these countries into adopting European ideas.

Research Area 3: Comparative Regionalism and Europe's External Relations

The EU perceives itself as a model for effective and legitimate governance to be emulated by other countries and regions. Moreover, the EU seeks to actively promote the development of genuine (intra-) regional economic and political cooperation, the building of issue-related regimes, and the creation of joint 
institutions for consultation and decision-making in its neighbourhood and beyond as well as between the world regions and the EU. In its attempt to promote regionalism as a distinct European idea (Bicci 2006; Grugel 2004), the EU constructs "new" regions, for example in Sub-Sahara Africa, which share few regional characteristics (for example economic interdependence) and have hardly developed a collective identity. What are the effects of these efforts at diffusing regionalism as a distinctively European idea? How are these efforts perceived by non-European partners (Harders 2005)? How do the institutionally complex processes of negotiation and re-negotiation change politics and identities on both ends? Can the EU's effort to export regional governance be compared with similar efforts by other actors, for example the U.S. or Great Britain promoting economic and political integration in Europe, Asia, and the Pacific? To what extent does regional integration (or liberal democracy and market economy for that matter) present genuinely European ideas instead of a global diffusion process (Simmons et al. 2006)? At the same time, Europe and the EU are themselves exposed to global processes of the diffusion of people and ideas for example through migration (Harders 2002). How does Europe respond to these economic, political, and cultural processes and how do they transform the European landscape? More specifically, how has the EU dealt with challenges to its "normative power" by national, international and transnational actors who reject European ideas and their normative hegemony and its unintended or "nasty" consequences?

The external dimension of the EU's transformative power is subject of various research projects in which Börzel and Risse are currently involved. In the framework of the Collaborative Research Center (SFB 700) "Governance in Areas of Limited Statehood" for which Risse serves as co-ordinator, Börzel directs a project on the EU's neighbourhood policies and its attempts to promote good governance in the Southern Caucasus (Börzel et al. 2007b, forthcoming). Several SFB projects investigate the efforts by international actors including the EU to promote democracy and human rights, to provide security and other public goods in areas of limited statehood. Moreover, Börzel and Risse co-direct a project with Stanford University's Center for Democracy, Development, and the Rule of Law comparing EU and U.S. efforts at democracy promotion worldwide (Börzel/Risse 2004, 2009, forthcoming-b). Finally, Risse co-directs a project on public and media discourses on the creation of a distinct European foreign and defence identity.

The Kolleg-Forschergruppe will enable us to bring these various research strands together and, in particular, to link our interests in diffusion processes with the research program of the SFB 700. This will also allow us strengthening the historical perspective. Ursula Lehmkuhl is cooperating with other historians in the SFB on the diffusion of governance ideas through colonialism in the Americas and East Asia. ${ }^{6}$ Moreover, we will have the possibility to counter the somewhat normative bias in the literature by systematically exploring the disruptive effects of the EU's attempt at region-building, particularly in its immediate neighbourhood. Finally, we take special interest in the role of migration for the diffusion of ideas out of as well as into the EU. Here, we will greatly benefit from the work of Cilja Harders and Jürgen Gerhards (Harders 2002; Gerhards/ Hans 2006). But the EU also seeks to diffuse its model of regional integration to other continents (Börzel/ Risse forthcoming-a). In order to explore the outcomes of these efforts and the mechanisms employed, we have to rely on external expertise. The Fellow Program will allow us bringing in experts from Africa,

6 Vgl. SFB 700, Project B3 „Colonial Governance und Mikrotechniken der Macht: Englische und französische Kolonialbesitzungen in Nordamerika, 1680-1760“ (Lehmkuhl); Project B4 „Wissen und Herrschaft: Scientific colonialism in den deutschen und japanischen Kolonien, 1884-1937“ (Conrad), and Project B5 „Herrschaftslegitimierung über Partizipation im kulturell heterogenen Raum: Lateinamerika zwischen Kolonie und postkolonialem Staat, 1759-1865 (Rinke); in: http://www.sfb-governance.de/teilprojekte/index.html; 26 October 2007. 
Asia, and Latin America. They will help us account for the receiving end of European diffusion processes and explore alternative influences.

For each of the three research areas, the Kolleg-Forschergruppe will study the role of the EU as the promoter and recipient of ideas analyzing the mechanisms and effects of internal and external diffusion processes. We will also systematically explore the linkages between the three research areas. For instance, by trying to bring third countries and other regions into compliance with its 'European' ideas, the EU projects its internal identity into its external relations and seeks to construct a distinct foreign policy identity. At the same time, compliance with European ideas becomes more likely, the more these ideas resonate with domestic identities, norms, and causal beliefs in third countries. Public spheres, in turn, are a major location for the contestation of European ideas that are not voluntarily accepted and adopted. While the EU can rely on legal coercion to overcome resistance in case of current and would-be members, it has to rely on more indirect diffusion mechanisms in its external relations beyond Europe. 


\section{Literature}

Anderson, Benedict 1991: Imagined Communities. Reflections on the Origin and Spread of Nationalism, London.

Bach, Maurizio (Ed.) 2000: Die Europäisierung nationaler Gesellschaften, in: Kölner Zeitschrift für Soziologie und Sozialpsychologie, Sonderheft 52: 40.

Banerjee, Abhijt V. 1992: A Simple Model of Herd Behavior, in: Quaterly Journal of Economics 107: 3, 797817.

Bauer, Michael/Knill, Christoph/Pitschel, Diana 2007: “Differential Europeanization in Eastern Europe: The Impact of Diverse EU Regulatory Governance Patterns, in: Journal of European Integration 29: 4, 405-423.

Berger, Helge/Eijffinger, Sylvester /de Haan, Jakob 2001: Central Bank Independence: Update on Theory and Evidence, in: Journal of Economic Surveys 15: 1, 3-40.

Berger, Helge/Kopits, George/Székely, István 2007: Fiscal Indulgence in Central Europe: Loss of the External Anchor?, in: Scottish Journal of Political Economy 54: 1, 116-135.

Besley, Timothy/Case, Anne 1995: Incumbent Behavior: Vote Seeking, Tax Setting and Yardstick Competition, in: American Economic Review 85, 25-45.

Bicci, Federica 2006: "Our Size Fits All": Normative Power Europe and the Mediterranean, in: Journal of European Public Policy 13: 2, 286-303.

Bogdandy, Armin von/Cruz Villalón, Pedro/Huber, Peter M. (Eds.) 2007: Handbuch lus Publicum Europaeum. Band I: Grundlagen und Grundzüge staatlichen Verfassungsrechts, Heidelberg.

Boli, John/Thomas, George M. 1999: Constructing World Culture. International Nongovernmental Organizations Since 1875, Stanford.

Bordignon, Massimo/Cerniglia, Floriana/Revelli, Federico 2004: Yardstick Competition in Intergovernmental Relationships: Theory and Empirical Predictions, in: Economics Letters 83: 3, 325-333.

Börzel, Tanja A. 2001: Non-Compliance in the European Union. Pathology or Statistical Artefact?, in: Journal of European Public Policy 8: 5, 803-824.

Börzel, Tanja A. 2003a: Environmental Leaders and Laggards in the European Union. Why There is (Not) a Southern Problem, London.

Börzel, Tanja A. 2003b: Guarding the Treaty: The Compliance Strategies of the European Commission, in: Börzel, Tanja A./Cichowski, Rachel (Eds.): The State of the European Union VI: Law, Politics, and Society, Oxford, 197-220.

Börzel, Tanja A. 2006: Coping with Accession - New Modes and EU Enlargement, in: Schuppert, Gunnar Folke (Eds.): Europeanization of Governance - The Challenge of Accession, Baden-Baden, 613641.

Börzel, Tanja A. 2007: EU Governance - Verhandlungen und Wettbewerb im Schatten von Hierarchie, in: Politische Vierteljahresschrift, Sonderheft 2007: 2.

Börzel, Tanja A. (Ed.) forthcoming-a: Coping with Accession to the European Union. New Modes of Governance in Southern, Central and Eastern Europe, Houndmills.

Börzel, Tanja A. forthcoming-b: European Governance - Negotiation and Competition in the Shadow of Hierarchy, in: Journal of Common Market Studies.

Börzel, Tanja A./Hofmann, Tobias/Sprungk, Carina 2003: Einhaltung von Recht jenseits des Nationalstaats. Zur Implementationslogik marktkorrigierender Regelungen in der EU, in: Zeitschrift für Internationale Beziehungen 10: 2, 247-286. 
Börzel, Tanja A./Dudziak, Meike/Hofmann, Tobias/Panke, Diana/Sprungk, Carina 2007a: Recalcitrance, Inefficiency and Support for European Integration. Why Member States Do (Not) Comply with European Law, in: CES Working Paper, Harvard University 148.

Börzel, Tanja A./Pamuk, Yasemin/Stahn, Andreas 2007b: Good Governance in the European Union, in: Berliner Arbeitspapiere zur Europäischen Integration, Center of European Studies, Freie Universität Berlin 07: 5.

Börzel, Tanja A./Pamuk, Yasemin/Stahn, Andreas forthcoming: Democracy or Stability? EU and US Engagement in the Southern Caucasus, in: Magen, Amichai/ McFaul, Michael/Risse, Thomas (Eds.): Democracy Promotion in the EU and the EU Compared, Houndmills.

Börzel, Tanja A./Risse, Thomas 2002: Die Wirkung Internationaler Institutionen: Von der Normanerkennung zur Normeinhaltung, in: Jachtenfuchs, Markus/Knodt, Michèle (Eds.): Regieren in internationalen Institutionen, Opladen, 141-182.

Börzel, Tanja A./Risse, Thomas 2004: One Size Fits All! EU Policies for the Promotion of Human Rights, Democracy, and the Rule of Law, in: paper presented for the Workshop on Democracy Promotion organized by the Center for Development, Democracy, and the Rule of Law, Stanford University, October 4-5, 2004.

Börzel, Tanja A./Risse, Thomas 2007: Europeanization: The Domestic Impact of EU Politics, in: Jorgensen, Knud Eric/Pollack, Mark A./Rosamund, Ben (Eds.): Handbook of European Union Politics, London, 483-504.

Börzel, Tanja A./Risse, Thomas 2009: Venus Approaching Mars? The European Union as an Emerging Civilian World Power, in: Berliner Arbeitspapiere zur Europäischen Integration, Center of European Studies, Freie Universität Berlin 09: 11.

Börzel, Tanja A./Risse, Thomas forthcoming-a: The Rise of (Inter-)Regionalism. The EU as a Model of Regional Integration, in: KFG Working Papers. Research College "The Transformative Power of Europe", Freie Universität Berlin.

Börzel, Tanja A./Risse, Thomas forthcoming-b: Venus Approaching Mars? The European Union's Approaches to Democracy Promotion, in: Magen, Amichai/ McFaul, Michael/Risse, Thomas (Eds.): Democracy Promotion in the US and the EU Compared, Houndmills.

Braun, Dietmar/Gilardi, Fabrizio 2006: Taking the Galton's Problem Seriously. Towards a Theory of Policy Diffusion, in: Journal of Theoretical Politics 45: 1, 298-322.

Brueckner, Jan 2003: Strategic Interaction Among Governments: An Overview of Empirical Studies, in: International Regional Science Review 26: 2, 175-188.

Busch, Per-Olof/Jörgens, Helge/Tews, Kerstin 2005: The Global Diffusion of Regulatory Instruments: The Making of a New International Environmental Regime, in: The ANNALS of the American Academy of Political and Social Sciences 598: 1, 146-167.

Checkel, Jeffery T. 2001: Why Comply? Social Learning and European Identity Change, in: International Organization 55: 3, 553-588.

Checkel, Jeffrey T. (Ed.) 2005: International Institutions and Socialization in Europe, in: International Organization 59: 4, Special Issue.

Christiansen, Thomas/Petto, Fabio/Tonra, Ben 2000: Fuzzy Politics Around Fuzzy Borders: The European Union's 'Near Abroad', in: Cooperation and Conflict 35: 4, 389-415.

Cowles, Maria Green/Caporaso, James A./Risse, Thomas (Eds.) 2001: Transforming Europe. Europeanization and Domestic Change, Ithaca, NY.

Diez, Thomas 2005: Constructing the Self and Changing Others: Reconsidering 'Normative Power Europe', in: Millenium 33: 3, 613-636.

Diez, Thomas/Stetter, Stephan/Albert, Matthias 2006: The European Union and Border Conflicts: The Transformative Power of Integration, in: International Organization 60: 3, 563-593. 
DiMaggio, Paul J. 1991: Constructing an Organizational Field as a Professional Project, in: Powell, Walter W/DiMaggio, Paul J. (Eds.): The New Institutionalism in Organizational Analysis, Chicago and London, 267-297.

DiMaggio, Paul J./Powell, Walter W. 1983: The Iron Cage Revisited: Institutional Isomorphism and Collective Rationality in Organizational Fields, in: American Sociological Review 48: 2, 147-160.

DiMaggio, Paul J./Powell, Walter W. 1991: The Iron Cage Revisited: Institutional Isomorphism and Collective Rationality in Organizational Fields, in: Powell, Walter W./DiMaggio, Paul J. (Eds.): The New Institutionalism in Organizational Analysis, Chicago, London, 63-82.

Dimitrov, Vesselin/Goetz, Klaus H./Wollmann, Hellmut 2006: Governing After Communism: Institutions and Policymaking, Lanham, MD.

Djelic, Marie-Laure 2007: Sociological Studies of Diffusion: Is History Relevant?, in: Uppsala Lectures in Business Uppsala University, Department of Business Studies.

Dolowitz, David P./Marsh, David 1996: Who Learns from Whom: a Review of the Policy Transfer Literature, in: Political Studies 44: 2, 343-357.

Dolowitz, David P./Marsh, David 2000: Learning from Abroad: The Role of Policy Transfer in Contemporary Policy-Making, in: Governance 13: 1, 5-24.

Eimer, Thomas R. 2008: Decoding Divergence in Software Regulation: Paradigms, Power Structures, and Institutions, in: Governance 21: 2, in press.

Elkins, Zachary/Guzman, Andrew T./Simmons, Beth A. 2006: Competing for Capital: The Diffusion of Bilateral Investment Treaties 1960-2000, in: International Organization 60: 4, 811-846.

Epstein, Rachel 2008: In Pursuit of Liberalism: The Power and Limits of International Institutions in Postcommunist Europe, Baltimore.

Evans, Mark/Davies, Jonathan 1999: Understanding Policy-Transfer. A Multi-Level, Multi-Disciplinary Approach, in: Public Administration 77: 2, 361-385.

Farrell, Mary 2007: From EU Model to External Policy? Promoting Regional Integration in the Rest of the World, in: Meunier, Sophie/McNamara, Kathleen R. (Eds.): Making History: European Integration and Institutional Change at Fifty, Oxford, 299-315.

Fehr, Ernst/Gächter, Simon 2002: Do Incentive Contracts Undermine Voluntary Cooperation?, in: Zürich Institute for Empirical Research in Economics Working Paper 34.

Fehr, Ernst/Rockenbach, Beate 2003: Detrimental Effects of Sanctions on Human Altruism, in: Nature 422, 137-140.

Finnemore, Martha 1996: National Interests in International Society, Ithaca.

Finnemore, Martha/Sikkink, Kathryn 1998: International Norm Dynamics and Political Change, in: International Organization 52: 4, 887-917.

Gerhards, Jürgen 2000: Europäisierung von Ökonomie und Politik und die Trägheit der Entstehung einer europäischen Öffentlichkeit, in: Bach, Maurizio(Eds.): Die Europäisierung nationaler Gesellschaften. Sonderheft 40 der Kölner Zeitschrift für Soziologie und Sozialpsychologie, Wiesbaden, 277-305.

Gerhards, Jürgen 2007: Cultural Overstretch? Differences Between Old and New Member States of the EU and Turkey, London.

Gerhards, Jürgen/Hans, Silke 2006: Zur Erklärung der Assimilation von Migranten an die Einwanderungsgesellschaft am Beispiel der Vergabe von Vornamen, in: Freie Universität Berlin: Berliner Studien zur Soziologie Europas 5.

Gerhards, Jürgen/unter Mitarbeit von Michael Hölscher 2005: Kulturelle Unterschiede in der Europäischen Union, Wiesbaden.

Gillingham, John 2003: European Integration 1950-2003, Cambridge.

Gleditsch, KristianSkrede/Ward, MichaelD. 2006: Diffusion and the International Context of Democratization, in: International Organization 60: 4, 911-933. 
Goetz, Klaus H. 2001: Making Sense of Post-Communist Central Administration: Modernization, Europeanization or Latinization, in: Journal of European Public Policy 8: 6, 1032-1051.

Goetz, Klaus H. 2005: The New Member States and the EU: Responding to Europe, in: Bulmer, Simon/ Lequesne, Christian (Eds.): The Member States of the European Union, Oxford, 254-280.

Goetz, Klaus H. 2006: Post-Communist Executives and European Governance, in: Schuppert, Gunnar Folke (Eds.): The Europeanisation of Governance, Baden-Baden, 93-131.

Goldstein, Judith/Keohane, Robert O. 1993: Ideas and Foreign Policy: An Analytical Framework, in: Goldstein, Judith/Keohane, Robert O. (Eds.): Ideas and Foreign Policy. Beliefs, Institutions and Political Change, Ithaca, 3-30.

Gourevitch, Peter 1978: The Second Image Reversed: The International Sources of Domestic Politics, in: International Organization 32: 4, 881-912.

Grazia, Victoria de 2005: Irresistible Empire: America's Advance Through Twentieth Century Europe, Cambridge, MA.

Graziano, Paolo/Vink, Maarten P. (Eds.) 2006: Europeanization: A Handbook for a New Research Agenda, Houndmills and London.

Grugel, Jean 2004: New Regionalism and Modes of Governance - Comparing US and EU Strategies in Latin America, in: European Journal of International Relations 10: 4, 603-626.

Haas, Peter M. 1992: Introduction: Epistemic Communities and International Policy Coordination, in: International Organization 46: 1, 1-36.

Häberle, Peter 1992: Theorieelemente eines allgemeinen juristischen Rezeptionsmodells, in: Juristenzeitung 47, 1033-1043.

Häberle, Peter 2006: Europäische Verfassungslehre, Baden-Baden.

Habermas, Jürgen 1981: Theorie des kommunikativen Handelns, Frankfurt a.M.

Hallerberg, Mark/Strauch, Rolf/Hagen, Jürgen von 2004: The Design of Fiscal Rules and Forms of Governance in European Union Countries, in: European Central Bank Working Paper 419.

Hannan, Michael T./Freeman, John H. 1977: The Population Ecology of Organizations, in: American Journal of Sociology 82: 5, 929-964.

Harders, Cilja 2002: Staatsanalyse von unten - urbane Armut und politische Partizipation in Ägypten, mikround mesopolitische Analysen unterschiedlicher Kairoer Stadtteile, Hamburg.

Harders, Cilja 2004: Gender and Security in the Mediterranean, in: Jünnemann, Annette (Eds.): EuroMediterranean Relations After September 11. International, Regional and Domestic Dynamics, London, 54-72.

Harders, Cilja 2005: Kopperation unter Bedingungen der Asymmetrie - Zehn Jahre Euro-Mediterrane Partnerschaft aus arabischer Sicht, in: Orient 2005: 3, 288-413.

Haveman, Heather A. 1993: Follow the Leader: Mimetic Isomorphism and Entry Into New Markets, in: Administrative Science Quaterly 38: 4, 593-627.

Herrmann, Richard K./Brewer, Marilynn/Risse, Thomas (Eds.) 2004: Transnational Identities. Becoming European in the EU, Lanham MD.

Hodson, D./Maher, I. 2001: The Open Method Of Coordination as a New Mode of Governance, in: Journal of Common Market Studies 39: 4, 719-746.

Holland, Martin 2003: The European Union and the Third World, Houndmills, Basingstoke.

Holzinger, Katharina/Jörgens, Helge/Knill, Christoph (Eds.) 2007a: Transfer, Diffusion und Konvergenz. PVS Sonderheft 38, Wiesbaden.

Holzinger, Katharina/Jörgens, Helge/Knill, Christoph 2007b: Transfer, Diffusion und Konvergenz: Konzepte und Kausalmechanismen, in: Politische Vierteljahresschrift, Sonderheft 38: 1, 11-38. 
Holzinger, Katharina/Knill, Christoph/Schäfer, Achim 2003: Steuerungswandel in der Europäischen Umweltpolitik?, in: Holzinger, Katharina/Knill, Christoph/ Lehmkuhl, Dirk (Eds.): Politische Steuerung im Wandel: Der Einfluß von Ideen und Problemstrukturen, Opladen, 103-129.

Huntington, Samuel P. 1991: The Third Wave: Democratization in the Late Twentieth Century, Norman OK.

Hurd, Ian 1999: Legitimacy and Authority in International Politics, in: International Organization 53: 2, 379-408.

Hurt, Stephen R. 2003: Co-operation and Coercion? The Cotonou Agreement Between the European Union and ACP States and the End of the Lomé Convention, in: Third World Quaterly 24: 1, 161-176.

Jachtenfuchs, Markus 1995: Ideen und internationale Beziehungen, in: Zeitschrift für Internationale Beziehungen 2: 2, 417-442.

Jachtenfuchs, Markus 1996: International Policy-Making as a Learning Process. The European Union and the Greenhouse Effect, Avebury.

Jachtenfuchs, Markus 2001: The Governance Approach to European Integration, in: Journal of Common Market Studies 39: 2, 245-264.

Jachtenfuchs, Markus 2002: Die Konstruktion Europas. Verfassungsideen und institutionelle Entwicklung, Weltpolitik im 21. Jahrhundert, Baden-Baden.

Jachtenfuchs, Markus 2005: The Monopoly of Legitimate Force. Denationalization, or Business as Usual?, in: Leibfried, Stephan/Zürn, Michael (Eds.): The Transformation of the State?, Cambridge, 37-52.

Jachtenfuchs, Markus/Diez, Thomas/Jung, Sabine 1998: Which Europe? Conflicting Models of a Legitimate European Political Order, in: European Journal of International Relations 4: 4, 409-445.

Jackson, Vicki C./Tushnet, Mark 1999: Comparative Constitutional Law, West Conshohocken, PA.

Jakobi, Anja P./Martens, Kerstin 2007: Diffusion durch internationale Organisationen: Die Bildungspolitik der OECD, in: Politische Vierteljahresschrift, Sonderheft 38: 1, 247-270.

Jepperson, Ronald/Wendt, Alexander/Katzenstein, Peter J. 1996: Norms, Identity, and Culture in National Security, in: Katzenstein, Peter J. (Eds.): The Culture of National Security: Norms and Identity in World Politics, New York, 33-75.

Johnston, Alastair Ian 2007: Social States. China in International Institutions, 1980-2000, Princeton.

Kaminisky, Graciela L./Reinhart, Carmen 2000: On Crises, Contagion, and Confusion, in: Journal of International Economics 51: 1, 145-168.

Kantner, Cathleen 2004: Kein modernes Babel. Kommunikative Voraussetzungen europäischer Öffentlichkeit, Wiesbaden.

Keck, Margaret/Sikkink, Kathryn 1998: Activists Beyond Borders: Advocacy Networks in International Politics, Ithaca.

Keller, Wolfgang 2002: Geographic Localization of International Technology Diffusion, in: American Economic Review 92: 1, 120-142.

Kelley, Judith G. 2004: Ethnic Politics in Europe. The Power of Norms and Incentives, Princeton.

Keohane, Robert O. 1984: After Hegemony. Cooperation and Discord in the World Political Economy, Princeton, NJ.

Keohane, Robert O./Milner, Helen V. (Eds.) 1996: Internationalization and Domestic Politics, Cambridge.

Koopmans, Ruud 2004: Integrated Report: Cross-National, Cross-Issue, Cross-Time, (The Transformation of Political Mobilisation and Communication in European Public Spheres), Berlin.

Legro, Jeffrey W. 1997: Which Norms Matter? Revisiting the 'Failure' of Internationalism, in: International Organization 51: 1, 31-63. 
Lehmkuhl, Ursula 2000: Entscheidungsprozesse in der internationalen Geschichte: Möglichkeiten und Grenzen einer kulturwissenschaftlichen Fundierung außenpolitischer Entscheidungsprozesse, in: Loth, Wilfried/Osterhammel, Jürgen (Eds.): Internationale Geschichte. Themen - Ergebnisse Aussichten, München, 187-207.

Lehmkuhl, Ursula 2001: Diplomatiegeschichte als internationale Kulturgeschichte: Ansätze, Methoden und Forschungsergebnisse zwischen Historischer Kulturwissenschaft und soziologischem Institutionalismus, in: Geschichte und Gesellschaft 27: 3, 394-423.

Lepsius, Rainer M. 1990: Interessen, Ideen und Institutionen, Opladen.

Levi-Faur, David 2002: Herding Towards a New Convention: On Herds, Shepherds and Lost Sheep in the Liberalization of the Telecommunication Industries, in: Nuffield College Working Papers in Politics 2002-W6.

Levi-Faur, David 2004: On the 'Net Impact' of Europeanization. The EU's Telecoms and Electricity Regimes Between the Global and the National, in: Comparative Political Studies 37: 1, 3-29.

Lundestad, Geir 1986: Empire by Invitation? The United States and Western Europe, 1945-1952, in: Journal of Peace Research 23: 3, 263-277.

Lütz, Susanne 2002: Der Staat und die Globalisierung von Finanzmärkten - Regulative Politik in Deutschland, Großbritannien und den USA, Frankfurt a.M.

Lütz, Susanne 2004: Convergence within national Diversity: The Regulatory State in Finance, in: Journal of European Public Policy 24: 2, 169-197.

Lütz, Susanne/Eberle, Dagmar 2007: On the Road to Anglo-Saxon Capitalism? German Corporate Governance Regulation between Market and Multilevel Governance, in: Comparative Research in Law and Political Economy (CLPE) Research Paper 3: 3, York University Toronto.

Magen, Amichai 2006: The Shadow of Enlargement: Can the European Union Neighbourhood Policy Achieve Compliance?, in: Columbia Journal of European Law 12, 495-538.

Magen, Amichai/Morlino, Leonardo (Eds.) 2008: Anchoring Democracy: External Influence on Domestic Rule of Law Development, London.

Mahoney, James 2000: Path Dependency in Historical Sociology, in: Theory and Society 29: 4, 507-548.

Majone, Giandomenico 1991: Cross-national Sources of Regulatory Policy Making in Europe and the United States, in: Journal of Public Policy 11: 1, 79-106.

Manners, Ian/Whitman, Richard G. 2003: The "difference engine". Constructing and representing the international identity of the European Union, in: Journal of European Public Policy 10: 3, 380404.

Mansfield, Edward/Milner, Helen 1999: The New Wave of Regionalism, in: International Organization 53: 3, 589-627.

March, James G./Olsen, Johan P. 1989: Rediscovering Institutions. The Organizational Basics of Politics, New York; London.

March, James G./Olsen, Johan P. 1998: The Institutional Dynamics of International Political Orders, in: International Organization 52: 4, 943-969.

Meseguer, Covodonga Yebra 2006: Rational Learning and Bounded Learning in the Diffusion of Policy Innovations, in: Rationality and Sociology 18: 1, 35-66.

Meyer, John W./Boli, John/George, Thomas M./Ramirez, Francisco O. 1997: World Society and the NationState, in: American Journal of Sociology 103: 1, 144-181.

Meyer, John W./Kamens, David H./Benavot, Aaron/Cha, Yua-Kyung/Wong, Suk-Ying 1992: School Knowledge for the Masses: World Models and National Primary Curricular Categories, Bristol, PA.

Meyer, John W./Rowan, Brian 1977: Institutionalized Organizations: Formal Structures as Myth and Ceremony, in: American Journal of Sociology 83: 2, 340-363. 
Meyer, John W./Rowan, Brian 1991: Institutional Organizations: Formal Structure as Myth and Ceremony, in: Powelll, Walter W./DiMaggio, Paul J. (Eds.): The New Institutionalism in Organizational Analysis, Chicago; London, 41-62.

Milner, Helen V. 1988: Resisting Protectionism: Global Industries and the Politics of International Trade, Princeton.

Myers, Daniel J. 2000: The Diffusion of Collective Violence: Infectiousness, Susceptibility, and Mass Media Networks, in: American Journal of Sociology 106: 1, 173-208.

Neuss, Beate 2000: Geburtshelfer Europas? Die Rolle der Vereinigten Staaten im europäischen Einigungsprozess 1945 bis 1958, Baden-Baden.

Owen, John M. 2002: The Foreign Imposition of Domestic Institutions, in: International Organization 56: 2, 375-409.

Paulmann, Johannes 2004: Grenzüberschreitungen und Grenzräume. Überlegungen zur Geschichte transnationaler Beziehungen von der Mitte des 19. Jahrhunderts bis in die Zeitgeschichte, in: Conze, Eckart/Lappenküper, Ulrich/Müller, Guido (Eds.): Geschichte der internationalen Beziehungen. Erneuerung und Erweiterung einer historischen Disziplin, Köln/Weimar/Wien, 169-196.

Payne, Roger A. 2001: Persuasion, Frames and Norm Construction, in: European Journal of International Relations 7: 1, 37-61.

Pernice, Ingolf 2001: Europäisches und nationales Verfassungsrecht, in: Veröffentlichungen der Vereinigung der Deutschen Staatsrechtslehrer (VVDStRL) 60, 148-193.

Pernice, Ingolf 2004: The Draft Constitution of the European Union, A Constitutional Treaty at a Constitutional Moment, in: Pernice, Ingolf/Maduro, Miguel Poiares (Eds.): A Constitution for the European Union: First Comments on the 2003 Draft of the European Convention, Baden-Baden, 13-21.

Pernice, Ingolf 2005: Zur Finalität Europas, in: Schuppert, Gunnar Folke/Pernice, Ingolf/Haltern, Ulrich (Eds.): Europawissenschaften, Baden-Baden, 743-786.

Polillo, Simone/Guillén, Mauro F. 2005: Globalization Pressures and the State: The Worldwide Spread of Central Bank Independence, in: American Journal of Sociology 110: 6, 1764-1802.

Powell, Walter W./DiMaggio, Paul J. (Eds.) 1991: The New Institutionalism in Organizational Analysis, Chicago, London.

Radaelli, Claudio M. 2000a: Policy Transfer in the European Union: Institutional Isomorphism as a Source of Legitimacy, in: Governance 13: 1, 25-44.

Radaelli, Claudio M. 2000b: Whither Europeanization? Concept Stretching and Substantive Change, in: European Integration on-line Papers 4: 8.

Randeria, Shalini 1999: Geteilte Geschichte und verwobene Moderne, in: Rüsen, Jörn/Leitgeb, Hanna/ Jegelka, Norbert (Eds.): Zukunftsentwürfe. Ideen für eine Kultur der Veränderung, Frankfurt a.M., 87-96.

Randeria, Shalini/Conrad, Sebastian 2002: Einleitung: Geteilte Geschichten - Europa in einer postkolonialen Welt, in: Randeria, Shalini/Conrad, Sebastian (Eds.): Jenseits des Eurozentrismus. Postkoloniale Perspektiven in den Geschichts- und Kulturwissenschaften, Frankfurt a.M., 9-49.

Raustiala, Kal/Slaughter, Anne Marie 2002: International Law, International Relations and Compliance, in: Carlsnaes, Walter/Risse, Thomas/Simmons, Beth A. (Eds.): Handbook of International Relations, London, 538-558.

Rein, Martin/Schön, Donald 1991: Frame-reflective Policy Discourse, in: Wagner, Peter/Weiss, Carol Hirschon/Wittrock, Björn/Wollmann, Hellmut (Eds.): Social Sciences and Modern States. National Experiences and Theoretical Crossroads, Cambridge, 261-289.

Risse, Thomas 1997: Between the Euro and the Deutsche Mark: German Identity and the European Union, Washington DC. 
Risse, Thomas 2000: "Let's Argue!" Communicative Action in International Relations, in: International Organization 54: 1, 1-39.

Risse, Thomas 2001: A European Identity? Europeanization and the Evolution of Nation-State Identities, in: Cowles, Maria Green/Caporaso, James A./Risse, Thomas (Eds.): Transforming Europe. Europeanization and Domestic Change, Ithaca, NY, 198-216.

Risse, Thomas 2002: Zur Debatte um die (Nicht-) Existenz einer europäischen Öffentlichkeit. Was wir wissen und wie es zu interpretieren ist, in: Berliner Debatte Initial 13: 5-6, 15-23.

Risse, Thomas 2003: The Euro between national and European identity, in: Journal of European Public Policy 10: 4, 487-503.

Risse, Thomas 2004a: Auf dem Weg zu einer europäischen Kommunikationsgemeinschaft: Theoretische Überlegungen und empirische Evidenz, in: Franzius, Claudia/Preuß, Ulrich K. (Eds.): Europäische Öffentlichkeit, Baden-Baden, 139-153.

Risse, Thomas 2004b: European Institutions and Identity Change: What Have We Learned?, in: Herrmann, Richard K./Risse, Thomas/Brewer, Marilynn (Eds.): Transnational Identities: Becoming European in the EU, Lanham MD, 247-271.

Risse, Thomas forthcoming: We the European Peoples? Identity, Public Sphere, and European Democracy, Ithaca NY.

Risse, Thomas/Engelmann-Martin, Daniela/Knopf, Hans Joachim/Roscher, Klaus 1999: To Euro or Not to Euro. The EMU and Identity Politics in the European Union, in: European Journal of International Relations 5: 2, 147-187.

Risse, Thomas/van de Steeg, Marianne 2007: The Emergence of a European Community of Communication: Insights from Empirical Research on the Europeanization of Public Spheres, Berlin - Utrecht, unv. M.

Rogers, Everett M. 2003: Diffusion of Innovations, New York.

Rose, Richard 1991: What is Lesson Drawing, in: Journal of Public Policy 11: 1, 3-33.

Rose, Richard 1993: Lesson-Drawing in Public Policy: A Guide to Learning across Time and Space, New Jersey.

Rosenfeld, Michel/Sajo, Andras/Baer, Susanne/Dorsen, Norman 2003: Comparative Constitutionalism. Cases and Materials, St. Paul, MI.

Salmon, Pierre 1987: Decentralization as an Incentive Scheme, in: Oxford Review of Economic Policy 3, 24-43.

Scharpf, Fritz W. 2003: Legitimate Diversity: The New Challenge of European Integration, in: Börzel, Tanja A./Cichowski, Rachel (Eds.): The State of the European Union VI: Law, Politics, and Society, Oxford, 79-104.

Scheipers, Sybille/Sicurelli, Daniela 2007: Normative Power Europe: A Credible Utopia?, in: Journal of Common Market Studies 45: 2, 435-457.

Schimmelfennig, Frank 2007: Europeanization beyond Europe, in: Living Reviews in European Governance 1: 1, in: http://europeangovernance.livingreviews.org/Articles//reg-2007-1/; 16 April 2009.

Schimmelfennig, Frank/Sedelmeier, Ulrich 2004: Governance by Conditionality: EU Rule Transfer to the Candidate Countries of Central and Eastern Europe, in: Journal of European Public Policy 11: 4, 661-679.

Schimmelfennig, Frank/Sedelmeier, Ulrich 2005: The Europeanization of Central and Eastern Europe, Ithaca, NY.

Schmidt, Susanne K. (Eds.) 2007: Mutual Recognition as a New Mode of Governance. 
Schneider, Volker 2001: Institutional Reform in Telecommunications: The European Union in Transnational Policy Diffusion, in: Cowles, Maria Green/Caporaso, James A./Risse, Thomas (Eds.): Transforming Europe. Europeanization and Domestic Change, Ithaca, 60-78.

Schreurs, Miranda 2004a: The Climate Change Divide: the European Union, the United States and the Future of the Kyoto Protocol, in: Vig, Neigel/Faure, Michael G. (Eds.): Green Giants? Environmental Policies of the United States and the European Union, Cambridge, MA, 207-230.

Schreurs, Miranda A. 2004b: EU Enlargement and the Environment: Institutional Change and Environmental Policy in Central and Eastern Europe, in: Environmental Politics 13: 1, $27-51$.

Scott, W. Richard/Meyer, John W. 1994: Institutional Environments and Organizations. Structural Complexity and Individualism, London et al.

Shapiro, Martin 1992: The European Court of Justice, in: Sbragia, Alberta M. (Eds.): Euro-Politics: Institutions and Policymaking in the 'New' European Community, Washington, DC, 123-156.

Sikkink, Kathryn 1991: Ideas and Institutions: Developmentalism in Brazil and Argentina, Ithaca NY.

Simmons, Beth A./Dobbin, Frank/Garrett, Geoffrey 2006: Introduction: The International Diffusion of Liberalism, in: International Organization 60: 4, 781-810.

Sinn, Hans-Werner 2003: The New Systems Competition, London.

Starr, Harvey 1991: Democratic Dominoes: Diffusion Approaches to the Spread of Democracy in the International System, in: Journal of Conflict Resolution 35: 2, 356-381.

Steinmo, Sven/Thelen, Kathleen/Longstreth, Frank (Eds.) 1992: Structuring Politics. Historical Institutionalism in Comparative Analysis, Cambridge; New York.

Stern, Klaus 2003: Die Idee der Menschen- und Grundrechte, in: Merten, Detlef/Papier, Hans-Jürgen (Eds.): Handbuch der Grundrechte in Deutschland und Eruopa, Band I: Entwicklungen und Grundlagen, Heidelberg, §1.

Strang, David 1990: From Dependency to Sovereignty: An Event History Analysis of Decolonization 18701987, in: American Sociological Review 55: 6, 846-860.

Strang, David/Meyer, John W. 1993: Institutional Conditions for Diffusion, in: Theory and Society 22, 487512.

Strang, David/Soule, Sarah A. 1998: Diffusion in Organizations and Social Movements: From Hybrid Corn to Poison Pills, in: Annual Review of Sociology 24, 265-290.

Sun, J.-M./Pelkmans, John 1995: Regulatory Competition in the Single Market, in: Journal of Common Market Studies 33: 1, 67-89.

Tallberg, Jonas 2003: European Governance and Supranational Institutions. Making States Comply, London; New York.

Tews, Kerstin 2002: Politiktransfer: Phänomen zwischen Policy-Lernen und Oktroi. Überlegungen zu unfreiwilligen Umweltpolitikimporten am Beispiel der EU-Osterweiterung, in: Zeitschrift für Umweltpolitik und Umweltrecht 25: 2, 173-201.

Tews, Kerstin/Busch, Per-Olof/Jörgens, Helge 2003: The diffusion of new environmental policy instruments, in: European Journal of Political Research 42: 2, 569-600.

Tiebout, Charles 1956: A Pure Theory of Local Expenditures, in: Journal of Political Economy 64, 416-424.

Trenz, Hans Jörg 2006a: Europa in den Medien. Die europäische Integration im Spiegel nationaler Öffentlichkeit, Frankfurt a.M.

Trenz, Hans Jörg 2006b: Europa in den Medien. Die europäische Integration im Spiegel nationaler Öffentlichkeit, Frankfurt a.M., New York.

Vachudova, Milada Anna 2005: Europe Undivided: Democracy, Leverage and Integration After Communism, Oxford. 
Vogel, David 1995: Trading Up: Consumer and Environmental Regulation in a Global Economy, Cambridge.

Watson, Alan 1974: Legal Transplants, Edinburgh.

Weitsmann, Patricia A./Schneider, Gerald 1997: Risky States: Implications for Theory and Policy Making, in: Schneider, Gerald/Weitsmann, Patricia A. (Eds.): Enforcing Cooperation. Risky States and Intergovernmental Management of Conflict, London, 283-294.

Werner, Michael/Zimmermann, Bénédicte 2002: Vergleich, Transfer, Verflechtung. Der Ansatz der Histoire croisée und die Herausforderung des Transnationalen, in: Geschichte und Gesellschaft 28: 4, 607 636.

Westney, Eleanor 1987: Imitation and Innovation, Cambridge, MA.

Wieacker, Franz 1967: Privatrechstgeschichte der Neuzeit. Unter besonderer Berücksichtigung der deutschen Entwicklung, Göttingen.

Wilson, John 1999: Theories of Tax Competition, in: National Tax Journal 52: 2, 269-304.

Youngs, Richard 2001: The European Union and the Promotion of Democracy, Oxford.

Zimmermann, Reinhard 1996: The Law of Obligations. Roman Foundations of the Civilian Tradition, Oxford. 
The Kolleg-Forschergruppe - Encouraging Academic Exchange and Intensive Research

The Kolleg-Forschergruppe (KFG) is a new funding programme launched by the German Research Foundation in 2008. It is a centrepiece of the KFG to provide a scientifically stimulating environment in which innovative research topics can be dealt with by discourse and debate within a small group of senior and junior researchers.

The Kolleg-Forschergruppe "The Transformative Power of Europe" brings together research on European affairs in the Berlin-Brandenburg region and institutionalizes the cooperation with other universities and research institutions. It examines the role of the EU as promoter and recipient of ideas, analyzing the mechanisms and effects of internal and external diffusion processes in three research areas:

- Identity and the Public Sphere

- Compliance, Conditionality and Beyond

- Comparative Regionalism and Europe's External Relations

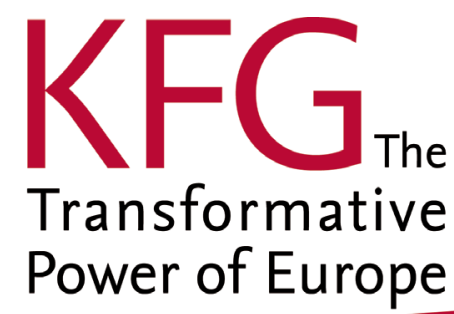

